\title{
Pengaruh Metode Pelatihan Berbasis Kompetensi dan Gaya Kognitif Terhadap Keterampilan Kesehatan dan Keselamatan Kerja Siswa
}

\author{
Yeti Yuni Perohmatin ${ }^{1}$, Rufi'i ${ }^{2}$, Hartono ${ }^{3}$ \\ ${ }^{1,2,3}$ Pascasarjana Teknologi Pendidikan Universitas PGRI Adi Buana Surabaya \\ ${ }^{1}$ Guru SMKS Yahari Sidoarjo Jawa Timur
}

\section{Edcomtech}

\section{Jurnal Kajian \\ Teknologi Pendidikan}

Volume 6, No 1, April 2021

151-161

Submitted 26-04-2020

Accepted 16-05-2020

Corresponding Author

Yeti Yuni Perohmatin

Email yettiyuni8@gmail.com

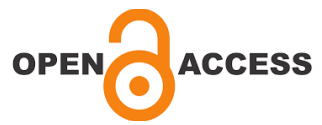

\begin{abstract}
Abstrak
Penelitian ini bertujuan untuk mengetahui: Pengaruh perolehan Keterampilan K3 siswa dengan menggunakan metode konvensional dan metode Pelatihan berbasis kompetensi, Pengaruh Keterampilan K3 siswa dengan gaya kognitiffield dependent dan gaya kognitif field independent, dan hubungan antara metode dan gaya kognitif terhadap keterampilan K3 siswa. peneliti menggunakan metode quasi experiment dan dengan menggunakan desain non-equivalent control group design dengan menerapkan desain faktorial $2 \times 2$ dalam rancangan eksperimennya. penelitian diambil secara sampling kelas acak. Penelitian tesis ini diuji dengan uji statistika Analysis of variance (ANOVA).Hasil penelitian menunjukkan (1) ada pengaruh perolehan Keterampilan K3 siswa yang belajar menggunakan metode konvensional dan metode Pelatihan berbasis kompetensi ( $F=104,942 ; p=0,000)$, (2) ada pengaruh Keterampilan K3 siswa yang belajar dengan gaya kognitif field dependent dan gaya kognitif field independent $(F=75,865 ; p=0,000)$ dan tidak ada hubungan antara metode dan gaya kognitif terhadap keterampilan $\mathrm{K} 3$ siswa $(F=3,283 ; p=0,073)$
\end{abstract}

Kata Kunci: Pelatihan berbasis kompetensi, kognitif, keterampilan

\begin{abstract}
This study aims to determine: The influence of the acquisition of K3 skills of students using conventional methods and competency-based training methods, The effect of $K 3$ skills of students with field dependent cognitive styles and independent field cognitive styles, the relationship between methods and styles cognitive ability of students' $K 3$ skills. The procedure used by researchers is a quasi experiment and using a non-equivalent control group design by applying a $2 \times 2$ factorial design in the experimental design. The technique was taken by random class sampling. This thesis analysis was tested with a statistical analysis of Analysis of variance (ANOVA). The results showed (1) there was an influence on the acquisition of $K 3$ skills of students who learner using conventional methods and competency-based training methods ( $F=104,942 ; p=0,000)$, (2) there were the influence of $K 3$ Skills of students learning with field dependent cognitive style and independent field cognitive style $(F=75.865 ; p=0.000)$ and there is no correlation between methods and cognitive style on students' $K 3$ skills ( $F=3.283 ; p=0.073)$
\end{abstract}

Keywords: competency based training, cognitive, skills 


\section{LATAR BELAKANG}

Dalam rangka melaksanakan program dan pelaksanaan kurikulum pembelajaran yang sinkron antara pendidikan dengan dunia kerja. Proses belajar mengajar tidak lepas dari keberadaan guru. Guru memiliki peran aktif dalam melaksanakan pendidikan dalam mencapai tujuan pendidikan yang dikehendaki melalui kegiatan pembelajaran dengan mengajar siswa.

Dalam proses belajar mengajar, sebaiknya guru mengacu pada standar kompetensi dan tujuan pembelajaran yang sudah ditentukan, diharapkan bisa memilih model maupun sarana pembelajaran yang idealnya disesuaikan dengan karakteristik siswa dan karakteristik mata pelajaran. Peran dan tugas guru dalam kegiatan pembelajaran antara lain menguasai dan mengembangkan materi pembelajaran, dan mempersiapkan program pembelajaran sehari-hari sesuai dengan Undang-Undang Nomor 14 tahun 2005, bahwa tugas tenaga pendidik adalah mendidik, mengajar, membimbing, mengarahkan, melatih, menilai dan mengevaluasi peserta didiknya dalam pembelajaran. Pembelajaran pada konsepnya PMK (Pendidikan Menengah Kejuruan) dengan menumbuh kembangkan seluruh potensi siswa agar memiliki wawasan kerja, keterampilan teknis bekerja, employability skill dan melakukan perubahan diri untuk siap hadapi perubahan dunia kerja.

Dasar-Dasar Keselamatan Laut (DKL) adalah mata pelajaran Dasar program keahlian (C2) yang memfokuskan tentang pelatihan penyelamatan jiwa manusia di laut bagaimana menyelamatkan diri maupun orang lain dalam keadaan darurat laut, setelah mengalami musibah di laut seperti tubrukan, kebakaran, kandas dan lain sebagainya, mengkaji dan menerapkan pelayanan pertolongan di kapal, mempraktekkan dan melaksanakan hubungan kemanusiaan dan tanggung jawab sosial di kapal. Maka perlunya dibuatnya Pengelolaan prosedur darurat kapal dengan tujuan sebagai panduan bagi pekerja kapal maupun peserta didik yang latihan praktik kerja lapangan dalam mengatasi keadaan darurat yang terjadi di kapal, sehingga bencana yang timbul dapat ditekan sekecil mungkin atau dihilangkan menurut (Santosa, 2018). Oleh karena itu perlunya siswa didik dan dilatih dalam pembelajaran dasar keselamatan laut diterapkan kepada siswa dengan program studi keahlian kemaritiman, selain itu siswa seharusnya dibekali sertifikat BST (Basic Safety Training), Buku Pelaut (Seaman Book) serta buku kesehatan (medical check up ) sebelum naik kapal baik hendak praktik lapangan maupun bekerja diatas kapal menurut (Setyowati, Suroto, \& Kurniawan, 2016). Dengan begitu seharusnya guru memahami dan mengerti macam-macam strategi dan metode pembelajaran yang sesuai karakteristik materi dan pelatihan siswa. Dalam memilih metode pembelajaran, kadar keaktifan siswa di kelas diperlukan karena proses sistem kerja memori sangat membantu perkembangan emosional siswa. Peran strategi atau model pembelajaran sangat besar terhadap perolehan konsep dalam memahami bahan pembelajaran, supaya hasil belajar sesuai dengan yang diharapkan maka perlu diupayakan suatu model pembelajaran yang membuat peserta didik memahami konsep pembelajaran.

Menurut Reni \& Kuswandi (2018) Belajar Mandiri merupakan faktor internal siswa yang pasif, artinya akan muncul dari akibat dampak langsung terciptanya kondisi lingkungan pembelajaran yang kondusif. Hal tersebut sesuai dengan paradigma yang menerangkan bahwa melalui desain pembelajaran yang berpusat pada siswa (learner centered instruction) merupakan bentuk pengkondisian.

Adapun konsep pembelajaran yang dapat digunakan sebagai acuan dalam mengembangkan belajar di Pendidikan Kejuruan Menengah (PMK) yang diantaranya; menumbuh kembangkan seluruh potensi peserta didik agar dapat memiliki wawasan kerja, entrepreneur, keterampilan teknis bekerja, employability skill, dan melakukan perubahan terhadap kesiapan perubahan tuntutan dunia kerja (Ningsih \& Sudira, 2016). Sekolah kejuruan akan menjadi efisiensi jika kegiatan pembelajarannya siswa dilatih dengan cara mengimitasi lingkungan kerja semirip mungkin dengan yang terjadi di tempat pekerjaan yang sebenarnya, kegiatan Pembelajaran pada sekolah kejuruan pelayaran dapat efektif jika pelatihan dilakukan sama seperti didunia pelayaran termasuk penggunaan peralatan navigasi dan mesin. Pembelajaran pada sekolah kejuruan akan lebih efektif sesuai keseimbangannya jika pembelajaran 
dipraktekkan secara langsung dan secara individu pada peserta didik dalam kebiasaan berpikir dan bertindak yang diperlukan dalam memanipulasi kompetensi keahlian (Kemdikbud, 2017). Kegiatan pembelajaran dengan menggunakan metode pelatihan berbasis kompetensi adalah merupakan sebuah metode pendekatan pembelajaran yang menekankan pada pengembangan dan peningkatan pengetahuan dan keterampilan siswa sesuai dengan kebutuhan pekerjaan. Pada metode ini, estimasi penilaian siswa dirancang sehingga dapat dipastikan bahwa setiap siswa telah mencapai pengetahuan dan keterampilan yang dibutuhkan pada setiap unit kompetensi masing-masing yang ditempuh.

Konsep tersebut adalah kegiatan pembelajaran dengan metode pelatihan berbasis kompetensi dan ini kemungkinan akan terbangun penyesuaian pada siswa sesuai dengan tuntutan dunia kerja dan akhirnya mereka memiliki kompetensi yang siap untuk memperoleh peluang dalam memasuki dunia kerja yang sebenarnya sehingga nantinya tujuan dari pelatihan ini adalah mencapai kompetensi yang telah dirancang (Kuswandi, Surahman, Thaariq, \& Muthmainnah, 2018) principles, investigation, decisions and represent products. This model is the right learning method used in various disciplines because it can improve thinking skills. This study aims to describe students' perceptions of the application of project-based learning models in the training program design and strategy courses by clustering data using the K-Means method. The result of the study shows that of the four clusters, they strongly agree, agree, disagree and strongly disagree, cluster 1 (agree. Selain model pembelajaran ada yang tidak kalah pentingnya dalam menyampaikan pengajaran di kelas. Hal ini dikarenakan setiap siswa memiliki ciri khas atau karakteristik tersendiri yang tidak dimiliki oleh individu lain (Susanto, 2015). Oleh sebab itu dapat dikatakan bahwa setiap siswa berbeda satu dengan yang lain. Selain berbeda tingkatan kecakapan memecahkan masalah, taraf kemampuan serta kecerdasan dalam berpikir, siswa juga dapat berbeda dalam mendapatkan, menyimpan serta menerapkan pengetahuannya. Siswa juga dapat berbeda strategi pendekatan terhadap situasi belajar, dalam cara siswa menerima, mengelompokkan dan mengkorelasikan pengalaman-pengalaman mereka, dalam cara bagaimana siswa menanggapi metode pengajaran tertentu. Perbedaan-perbedaan antar individu yang menetap dalam cara menyusun dan mengolah informasi serta pengalaman-pengalaman ini dikenal gaya kognitif. Oleh karena gaya kognitif menyangkut intelektual seseorang dalam memproses dan menyimpan informasi, maka peneliti mengangkat karakteristik gaya kognitif sebagai faktor yang dapat mengiringi dan mempengaruhi keterampilan K3 Siswa.

Berdasarkan uraian tersebut, maka penelitian ini mengkaji tentang: (1) pengaruh perolehan hasil Keterampilan K3 siswa antara siswa yang belajar menggunakan metode konvensional dan metode Pelatihan berbasis kompetensi, (2) pengaruh Keterampilan K3 siswa antara siswa yang belajar dengan gaya kognitif field dependent dan gaya kognitif field independent, (3) hubungan antara metode dan gaya kognitif terhadap keterampilan K3 siswa.

\section{METODE}

Penelitian ini merupakan penelitian Quasi experimental design atau rancangan eksperimen semu. Quasi experimental design digunakan untuk menguji pengaruh pembelajaran latihan dasar keselamatan laut dengan metode pelatihan berbasis kompetensi dan gaya kognitif terhadap keterampilan K3 Siswa. Dalam penelitian ini dirancang menurut versi NonEquivalent control group design dengan teknik pengukuran dua faktor.

Penelitian ini melibatkan satu variabel bebas dengan metode pelatihan berbasis kompetensi, gaya kognitif $\mathrm{FI}$ dan FD adalah Variabel moderator. Variabel Moderator diteliti pengaruhnya terhadap keterampilan K3 siswa. penelitian ini dilakukan pada tanggal 9 Januari sampai dengan 20 Maret 2020 di SMK Pelayaran Yahari Sidoarjo. Di penelitian ini populasinya adalah siswa kelas XI yang berjumlah 109 siswa dan terbagi dalam 2 kelas dengan 2 jurusan Nautika kapal niaga dan Jurusan Teknika kapal niaga. Teknikpengambilansampelmenggunakan cluster random sampling, untuk kelas jurusan nautika sebagai kelas kontrol dan jurusan teknika sebagai kelas eksperimen. Kelas kontrol diberi perlakuan metode konvensional dan 
pada kelas eksperimen diberi perlakuan model Pelatihan berbasis kompetensi. Rancangan ini merupakan modifikasi dari Pretest dan postest control group design.

Teknik pengumpulan data dalam penelitian ini dilakukan dengan tes instrumen GEFT untuk gaya kognitifnya dan tes objektif dengan soal multiple choice atau pilihan ganda sebanyak 20 soal yang telah sama-sama diuji instrumen melalui uji validitas dan reabilitasnya. Untuk tes Group Embedded Figures Test (GEFT) sebanyak 25 butir soal yang terdiri dari 3 bagian, yang pertama berjumlah 7 butir soal, yang kedua 9 butir soal dan yang ketiga 9 butir soal dan yang dianilai adalah soal yang kedua dan yang ketiga.

Pada uji validitas dan reliabilitas sebelum diterapkan di kelas eksperimen dan kontrol, maka instrumen tes diujikan ke kelompok lain, bukan kelompok sampel dimana konsistensi internal dilakukan dengan menghitung koefisien korelasi antara masing-masing butir soal dengan skor total pembelajar, atau korelasi Product Moment (PM) yang dihitung dengan koefisien korelasi soal dan pembelajar.

Dari perhitungan hasil korelasi tersebut menghasilkan koefisien korelasi yang digunakan untuk mengukur tingkat validitas item-item instrumen guna untuk menentukan apakah item tersebut layak digunakan atau tidak. Untuk menentukan layak dan tidaknya suatu item yang akan digunakan maka perlu dilakukan uji signifikansi koefisien korelasi pada taraf signifikansi 0.05, maka artinya validnya suatu item jika korelasi signifikan terhadap skor total. Dalam menguji tes validitas ini menggunakan program IBM SPSS-PC 19.0 for Windows. Teknik pengujian tes validitas dengan menggunakan Produk Momen Person atau Corelation Bivariate Person. Untuk menganalisis ini dengan cara menghubungkan masing-masing skor item dengan skor total. Skor total yaitu total dari jumlah keseluruhan item. Pertanyaan dari masingmasing item soal yang berkorelasi signifikan dengan skor total menunjukkan item-item tersebut mampu memberikan dukungan dalam mengungkap a valid, maka dari itu instrumen soal dari item-item pertanyaan berkorelasi signifikan terhadap total skor maka dinyatakan valid. Hasil dari uji tes validitas gaya kognitif memiliki semua butir probabilitasnya lebih kecil dari kriteria signifikansi 0,05. Hasil pengujian tes ini menunjukkan bahwa 18 butir tes gaya kognitif tersebut valid. Untuk mendukung tercapainya validitas isi, dalam penyusunan soal perlu dibuatkan kisi-kisi soal.

Adapun pada uji rendah tingginya reliabilitas, secara bukti bisa ditunjukan oleh suatu angka yang disebutnilai koefisien reliabilitas. Nilai Reliabilitasyang tinggiditunjukandengannilaixyangmendekatiangka 1 (satu). Secara umum nilai ketentuan reliabilitas yang dianggap sudah cukup memuaskan jika lebih besar sama dengan 0,700 ( $\geq 0.700$ ) Pengujian reliabilitas instrumen dengan menggunakan rumus Alpha Cronbach dikarenakan instrumen penelitian ini berbentuk angket soal dan skala bertingkat. Untuk dapat menginterpretasikan derajat reliabilitas, agar dapat diketahui hasil hitung reliabilitas maka hasil tersebut dapat dijadikan sebagai alat evaluasi yang dapat digunakan tolak ukur atau pedoman, jika (1) nilai alpha kurang dari 0,50 maka Derajat Reliabilitas rendah, (2) nilai alpha 0.50 s.d 0.70 maka Derajat Reliabilitas moderat, (3) nilai alpha 0.70 s.d 0.90 maka Derajat Reliabilitas tinggi, (4) nilai alpha lebih dari 0,90 maka Derajat Reliabilitas sempurna. Hasil uji reliabilitas dengan koefisien Alpha Cronbach's memiliki koefisien reliabilitas Alpha Cronbach's sebesar 0,881 >0,70 (Linn, 1989). Hasil uji coba tes gaya kognitif dinyatakan semua item reliabel dan semua tes secara konsisten memiliki reliabilitas yang kuat. Hasil uji reliabilitas dengan koefisien Alpha Cronbach's memiliki koefisien reliabilitas Alpha Cronbach's sebesar 0,902 > 0,70 (Linn, 1989). Hasil uji coba tes instrumen soal dinyatakan reliabel sempurna.

\section{HASIL DAN PEMBAHASAN}

Dari hasil penelitian yang telah dilakukan,maka hasil penelitian disuguhkan dalam bentuk penyajian data yang sesuai dengan hasil penelitian yang berisi: (1) deskripsi data dan (2) pengujian hipotesis. Berdasarkan akhir analisis penelitian ini dengan sampel berjumlah 109 siswa. berikut ini dipaparkan perihal sampel penelitian berlandaskan gaya kognitif dan metode pembelajaran (Tabel 1).

\section{Tabel 1 Keadaan Sampel Penelitian gaya} Kognitif dan Metode Pembelajaran

\begin{tabular}{llll}
\hline Gaya & Metode & Metode & Jumlah \\
Kognitif & Konvensional & PBK & \\
\hline FD & 38 & 34 & 72 \\
FI & 17 & 20 & 37 \\
\hline Jumlah & 55 & 54 & 109 \\
\hline
\end{tabular}


Tabel 5, menunjukkan dari 109 siswa sampel penelitian, 72 siswa yang bergaya kognitif fielddependent (FD) dan 37 siswa bergaya kognitif field-Independent (FI), kelompok siswa yang diajar dengan metode Konvensional adalah 38 siswa yang bergaya kognitif field dependent dan 17 siswa yang bergaya kognitif field independent. Kelompok siswa yang diajar dengan metode Pelatihan Berbasis Kompetensi adalah 34 siswa yang bergaya kognitiffield-dependent dan 20 siswa yang bergaya kognitif Field-Independent. Data tersebut memberikan gambaran bahwa jumlah siswa yang bergaya kognitif Field-Independent (FI) lebih sedikit dibandingkan dengan jumlah siswa bergaya kognitif Field-dependent (FD). Pada normalitas diuji secara univarian untuk skor keterampilan k3 siswa dengan uji KolmogrovSmirnov. Berdasarkan tes normalitas maka data dilakukan sesuai dengan pengelompokan data bersumber hasil posttest pada kedua jurusan atau kelompok siswa, baik yang diajarkan dengan metode konvensional maupun metode pelatihan berbasis kompetensi. Pada tabel 2 berikut ini disajikan hasil uji normalitas data-data penelitian.

Tabel 2. Uji Normalitas KS

\begin{tabular}{cccc}
\hline & \multicolumn{3}{c}{ Kolmogorov-Smirnov ${ }^{\mathrm{a}}$} \\
\cline { 2 - 4 } & Statistic & $\mathrm{df}$ & Sig. \\
\hline $\begin{array}{c}\text { Standardized } \\
\text { Residual for } \\
\text { Keterampilan }\end{array}$ & .060 & 109 & $.200^{*}$ \\
\hline
\end{tabular}

Pada tabel.2 terlihat bahwa nilai probabilitas tes normality Kolmogrov-Smirnov adalah 0.200. Hasil uji Kolmogrov-Smirnov bahwa perolehan nilai keterampilanK3siswamempunyainilaiprobabilitas lebih besar dari batas kriteria signifikansi 0,05. Hasil dari pengujian ini menunjukkan bahwa keterampilan K3 siswa mempunyai sebaran normal. Pada Uji homogenitas data penelitian dilakukan terhadap variabel terikat dan untuk menguji kesamaan matrik varian-koovarian skor perolehan keterampilan K3 siswa secara univarian dengan uji Lavene's. Hasil analisis pada tabel 3.

Tabel 3. Uji Homogenitas

\begin{tabular}{c|c|c|c}
\hline$F$ & $d f 1$ & $d f 2$ & Sig. \\
\hline 1.233 & 3 & 105 & .301 \\
\hline
\end{tabular}

Pada Tabel.3 menunjukkan nilai probabilitas $\alpha$ $=0,301$. Nilai probabilitas yang dicapai dari hasil perhitunganternyatalebih besardarinilai probabilitas $\alpha=0,05$, Berdasarkan kriteria pengujian tercantumitu dapat dinyatakan data variabel terikat keterampilan K3 siswa pada kelompok eksperimen memiliki varian-koovarian yang sama dan telah memenuhi asumsi homogenitas. Pengujian hipotesis Data hasil keterampilan K3 siswa dalam pembelajaran Dasar Keselamatan Laut dengan metode konvensional dan metode Pelatihan Berbasis Kompetensi. Data dianalisis dengan uji two way Anova. Tujuan analisis statistika yaitu untuk mengetahui apakah terdapat pengaruh antara dua kelompok tersebut, disajikan pada tabel 4 Hasil Uji anova $2 \times 2$ berikut ini;

Tabel 4 Hasil Analisis Uji Anova Tes Keterampilan K3 Siswa

\begin{tabular}{lrrrrr}
\hline Source & $\begin{array}{c}\text { Type III Sum } \\
\text { of Squares }\end{array}$ & \multicolumn{1}{c}{ df } & \multicolumn{1}{c}{ Square } & \multicolumn{1}{c}{ S } & \multicolumn{1}{c}{ Sig. } \\
\hline Corrected Model & $6466.750^{\mathrm{a}}$ & 3 & 2155.583 & 74.255 & .000 \\
Intercept & 671194.740 & 1 & 671194.740 & 23121.012 & .000 \\
Metode & 3046.443 & 1 & 3046.443 & 104.942 & .000 \\
Gaya_Kognitif & 2202.328 & 1 & 2202.328 & 75.865 & .000 \\
Metode * Gaya_Kognitif & 95.310 & 1 & 95.310 & 3.283 & .073 \\
Error & 3048.113 & 105 & 29.030 & & \\
Total & 732461.000 & 109 & & & \\
Corrected Total & 9514.862 & 108 & & & \\
\hline
\end{tabular}


Hasil Hipotesis pada tabel 4 menunjukkan bahwa;(1) Nilai $F$ pada metode terhadap keterampilan K3 siswa adalah 104.942 dan probabilitasnya sebesar 0,000 $<0,05$ maka dikatakan $\mathrm{HO}$ ditolak. Hasil pengujian memiliki arti bahwa, ada pengaruh perolehan hasil Keterampilan K3 siswa antara siswa yang belajar menggunakan metode konvensional dan metode Pelatihan berbasis kompetensi. (2) Nilai F pada gaya kognitif terhadap Keterampilan K3 siswa adalah 75.865 dan probabilitasnya sebesar $0,000<0,05$ maka dikatakan HO ditolak. Hasil pengujian mengandung arti bahwa, ada pengaruh keterampilan K3 siswa antara siswa yang belajar dengan gaya kognitif FD dan gaya kognitif FI. (3) Nilai F pada baris interaksi Metode*Gaya_Kognitif terhadap Keterampilan K3 siswa adalah 3.283 dan probabilitasnya sebesar 0,073 > 0,05 maka dikatakan $\mathrm{HO}$ diterima. Hasil pengujian mempunyai arti bahwa, tidak ada hubungan antara metode dan gaya kognitif terhadap keterampilan K3 Siswa.

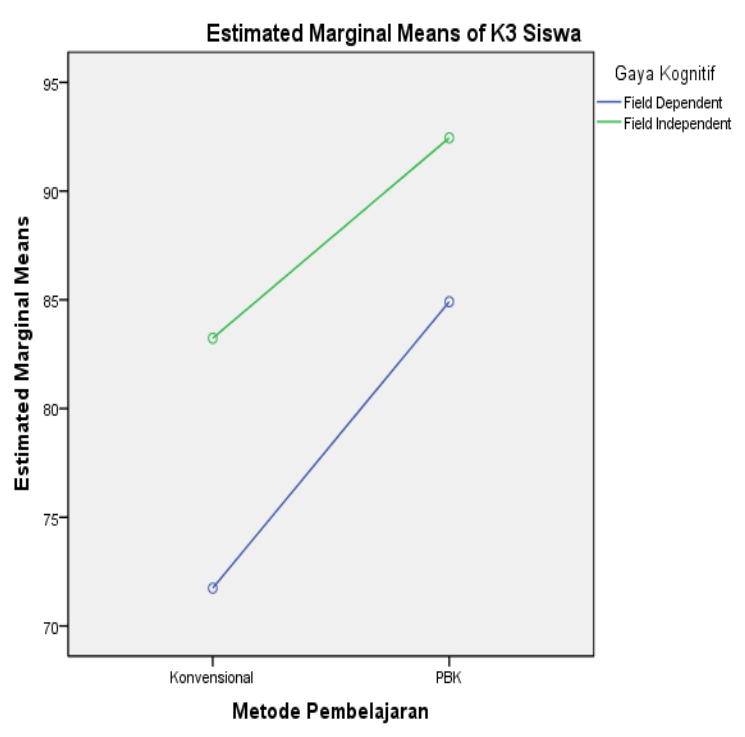

\section{Gambar 1 interaksi Metode*Gaya_Kognitif terhadap Keterampilan K3 siswa}

\section{Pembahasan}

Pembahasan hasil penelitian mencangkup penjelasan tentang pengaruh pembelajaran latihan dasar keselamatan laut dengan metode pelatihan berbasis kompetensi dan gaya kognitif terhadap keterampilan K3 siswa SMK YAHARI Sidoarjo. Pembahasan dalam hal ini merupakan upaya pendalaman eksperimen dengan pengetahuan teori dan hasil penelitian yang sudah ada dan memberikan makna atau interprestasi terhadap implikasi yang terjadi. Pembahasan dalam sub-sub bab menjelaskan pengaruh variabel bebas yang diteliti metode (konvensional dan pelatihan berbasis kompetensi) dan gaya kognitif FI maupun FD terhadap variabel terikat (Keterampilan K3 siswa). Dalam pembahasan ini dibahas 3 (tiga) hal, yaitu (1) pengaruh metode pembelajaran terhadap keterampilan K3 siswa, (2) pengaruh gaya kognitif terhadap keterampilan K3 siswa, dan (3) hubungan metode pembelajaran dan gaya kognitif terhadap keterampilan K3 siswa.

\section{Pengaruh metode pembelajaran pelatihan berbasis kompetensi terhadap keterampilan $\mathrm{K} 3$ siswa.}

Hasil pengujian hipotesis 1 membuktikan bahwa ada pengaruh perolehan hasil Keterampilan K3 siswa antara siswa yang belajar menggunakan metode konvensional dan metode Pelatihan berbasis kompetensi. Hasil pengujian hipotesis 2 menerangkan bahwa kegiatan belajar mengajaran dengan menggunakan metode konvensional kurang efektif dalam pembelajaran latihan dasar keselamatan laut. Pada kegiatan belajar mengajar dengan metode konvensional dimana seorang guru hanya memberikan pembelajaran teori serta ceramah. Pada mata pelajaran dasar keselamatan laut pembelajaran dengan metode konvensional dimana guru hanya memberikan gambaran teory-teory tentang keselamatan kerja di laut tanpa memberikan praktik cara teknik penyelamatan di kapal. Metode konvensional ini tidak bisa mengembangkan cara berpikir siswa untuk memecahkan masalah jika timbul pada dunia kerja, yaitu pada dunia pelayaran khususnya cara penanganan keselamatan di laut, maka siswa akan bingung dalam menyelesaikan masalah di dunia kerja.

Hasil pengujian hipotesis 2 didukung oleh Temuan penelitian ini sesuai dengan penelitian sebelum-belumnya. (Hidayat \& Sa'ud, 2015; Ningrum, Degeng, \& Ulfa, 2019; Nurhajati \& Bachri, 2018; Paryanto, Soemawidagdo, \& Sunarso, 2013; Prayogo, Arifin, Erliyani, \& Yuntoro, 2018; Surachim, 2013; Wedi, 2017; Yamin, 2020)2018; Paryanto, Soemawidagdo, \& Sunarso, 2013; Prayogo, Arifin, Erliyani, \& Yuntoro, 2018; Surachim, 2013; Wedi, 2017; Yamin, 2020. Uraian pendukung pengujian hipotesis 2 tersebut didapatkan oleh pendukung Konsep 
dan masalah penerapan metode pembelajaran upaya peningkatan mutu pembelajaran melalui konsistensi teoritis-praktis penggunaan metode pembelajaran menurut Wedi (2017) beliau mengatakan bahwa minimnya kualitas pembelajaran dikarenakan lemahnya memilih metode pembelajaran yang tepat, karena dengan metode pembelajaran yang sesuai dan konsisten akan meningkatkan kualitas pembelajaran. Jadi jika metodenya tepat dalam pembelajaran maka dapat meningkatkan kompetensi siswa baik dari segi pengetahuan, hasil belajar maupun keterampilan K3 siswa.

Didapatkan pendukung Model Pendidikan Dan Pelatihan Berbasis Kompetensi Bagi Widyaiswara Muda Menurut Hidayat dan Suud (2015) beliau berdua mengatakan bahwa untuk meningkatkan kompetensi siswa maka diperlukan metode pembelajaran yang tepat, metode Pelatihan Berbasis Kompetensi (PBK) inilah yang merupakan metode yang tepat karena dirasa paling memenuhi standar Kompetensi bagi sekolah kejuruan. Darul Prayogo et.al (2018) Menunjukkan bahwa dalam penerapan metode pelatihan berbasis kompetensi dapat dilihat hasil pelaksanaan kurikulum terlaksana dengan kategori baik dengan prosentase $80 \%$.

Nurhajati, W. A., dan Bachri, B. S. (2018) dalam penelitiannya Pengembangan Kurikulum Diklat (Pendidikan dan Pelatihan) Berbasis Kompetensi dalam Membangun Profesionalisme dan Kompetensi Pegawai Negeri Sipil (PNS) mereka mengatakan bahwa penerapan metode pelatihan berbasis kompetensi ini merupakan metode yang dibutuhkan siswa untuk mengembangkan pengetahuan dan keterampilan guna persiapan masuk ke dunia kerja. Terdapat penelitian pendukung Pengaruh Sikap dan Penguasaan Siswa tentang Materi Kesehatan dan Keselamatan Kerja (K3) terhadap Pelaksanaan Kesehatan dan Keselamatan Kerja (K3) di Bengkel Teknik Kendaraan Ringan SMK Negeri 1 Rejotangan menurut Sugeng Solahudin, Mardji, dan Anny Martiningsih (2017), dalam penelitiannya mereka menggambarkan tentang penguasaan keterampilan K3 siswa dengan tujuan supaya siswa mempunyai kesadaran dan berperilaku menjaga kesehatan dan keselamatan kerja pada dirinya pelaku yang menjalankan materi kesehatan dan keselamatan Kerja K3.

M. Yamin (2016) menggambarkan perilaku keselamatan dan dan kesehatan kerja siswa sangat penting dalam melaksanakan praktikum di ruang praktik. Dalam penelitian tentang dasar keselamatan laut terdapat pendukung penelitian Pengelolaan Kecelakaan Pada Kapal menurut Sigit (2018) mengatakan bahwa pentingnya mempelajari dasar keselamatan laut karena untuk safety pencegahan kecelakan di laut serta cara penanganan kapal dalam keadaan darurat.

Menurut Surahim (2013) bahwa upaya guru dalam pengembangan layanan pembelajaran berbeda, kontradiktif, kompleks. Gunakan metode variasi, media, diselingi humor, contoh, variasi bertanya. Rencana pembelajaran adaptif, mudah dipahami, menguraiisidantujuan, kelemahan yang harus ditangani. Dimensi kompetensi profesional membutuhkan pengembangan kompetensi guru, Dimensi manajemen fasilitas memerlukan perbaikan menggunakan manajemen standar, penyimpanan, analisis kebutuhan. Dimensi terpadu, menuntut guru sebagai motivator siswa, mengembangkan fasilitas pembelajaran, layanan pembelajaran dan sinkronisasi prakerin. Dimensi sosio-kultural membutuhkan pengembangan objek pembelajaran sehingga mencerminkan sosok lulusan SMK yang memahami kehidupan sosial-budaya, hubungan dengan orang lain yang penting, memahami nilai dan norma, serta memahami perubahan aspek kehidupan.

Ningrum.,dkk (2019), mengatakan bahwa Hasil penelitiannya menunjukkan bahwa penerapan strukturkurikulummuatanlokalyaituketerampilan membatik dapat mengembangkan keterampilan produk kerajinan batik, dapat memupuk cinta tanah air tentang budaya serta dapat melestarikan budaya batik. Pendukung penelitian Model Model Pembelajaran Competence Based Training (CBT) Berbasis Karakter Untuk Pembelajaran Praktik menurut Paryanto., dkk (2019) dalam penelitiannya mengatakan dalam pembelajaran terdapat perbedaan pelaksanan pembelajaran competency base training (CBT) dengan yang tidak menggunakan metode CBT, dan penerapan metode tersebut efektif untuk meningkatkan lulusan siswa sekolah menengah kejuruan (SMK).

Temuan-temuan penelitian tersebut mendukung temuan penelitian ini. Bahwa Metode pelatihan berbasis kompetensi lebih baik daripada metode konvensional di dalam pelaksanaan kegiatan pembelajaran materi dan praktik ilmu kejuruan dalam pendidikan sekolah menengah kejuruan., Siswa juga dapat menerapkan langsung 
materi tersebut dalam kegiatan praktik maupun pelatihan.

\section{Pengaruh gaya kognitif terhadap keterampilan K3 siswa}

Hasil pengujian hipotesis 3 membuktikan bahwa ada perbedaan perolehan hasil Keterampilan K3 siswa antara siswa yang belajar dengan gaya kognitif Field-Dependent dan Field-Independent. Hasil pengujian hipotesis ini mengandung arti keterampilan K3 siswa dengan gaya kognitif $\mathrm{Fl}$ lebih bagus nilai keterampilannya daripada siswa dengan gaya kognitif FD pada siswa SMK Pelayaran Yahari Sidoarjo. Hal ini menunjukkan bahwa siswa dengan gaya kognitif Field-Independent cocok digunakan untuk materi pelatihan dasar keselamatan laut, didapatkan pendukung Pengaruh Metode Problem Solving dan Gaya Kognitif terhadap Kemampuan Analisis Siswa menurut Sanjaya 2018). Dia mengatakan Setiap individu dalam arti peserta didik mempunyai ciri dan karakter tersendiri yang menjadi ciri khas masing-masing individu baik kecerdasan, pengetahuan, keterampilan maupun gaya hidup, maka gaya kognitif ada korelasinya dengan prestasi hasil belajar dan keterampilan individu dalam arti siswa.

Menurut Aldarmono (2012) menjelaskan bahwa setiap individu siswa memiliki gaya kognitif masingmasing, adapun gaya kognitif tersebut terbagi 2 yaitu gaya kognitif FI dan FD. Pada siswa yang bergaya kognitif Fl lebih unggul untuk memahami, menerima materi dibandingkan dengan individu siswa yang memiliki gaya kognitif FD. Sedangkan pada siswa yang memiliki gaya kognitif FD individu tersebut lebih sulit untuk memahami, menerima materi pembelajaran. Dalam penelitian Murtafiah (2017) mengatakan bahwa pada individu siswa dalam menerima materi pembelajaran matematika siswa yang memiliki gaya kognitif Fl lebih mampu dan paham akan pengungkapan kalimat-kalimat verbal kedalam kalimat matematika, sedangkan pada individu siswa yang memiliki gaya kognitif FD sulit memahami dan mencerna materi matematika dalam pengungkapan bahasa verbal ke dalam kalimatmatematika,meskipunmengertidanmampu bahasa verbal tetapi sulit untuk mengungkapkannya dalam bentuk kalimat matematika.

Menurut Mustafid, Wedi, \& Adi (2020) Dalam Penelitiannya menunjukkan bahwa gaya belajar mahasiswa memiliki beberapa dampak penentu seperti tingkat kenyamanan belajar, dan penentu hasil. Dengan demikian para pendidik harus bijak ketika berhadapan dengan karakteristik belajar peserta didik yang bervariasi, karena pada hakikatnya hal tersebut dapat dipengaruhi oleh faktor bawaan internal yang sulit untuk dikondisikan.

Purwanti, Pratiwi, \& Rinaldi (2016) mengatakan bahwa siswa yang memiliki gaya kognitif FI dan FD maka memiliki kemampuan berbeda. Dalam hasil analisis data penelitiannya menghasilkan terdapat perbedaan penggunaan metode pembelajaran discovery learning dan memiliki perbedaan gaya kognitif pada mata pelajaran matematikanya tetapi keduanya antara gaya kognitif dan metode discovery learning tidak memiliki hubungan terhadap pemahaman mata pelajaran matematika. Riding \& Rayner (2013) menjelaskan gaya kognitif merupakan pendekatan dalam bentuk pengelompokan serta gambaran informasi secara konsisten. Dimensi psikologi merupakan gaya kognitif tentang karakter seseorang untuk merespon segala informasi yang diterima. Gaya kognitif merupakan perolehan, pengelompokkan, penggambaran dan proses informasi yang dilakukan individu secara konsisten.

Fauzi (2019) menyimpulkan dalam penelitiannya bahwa Gaya kognitif merupakan Teknik yang disukai oleh individu berkaitan dengan menerima, memproses info, dan mencari solusi guna memecahkan permasalahan dengan relatif tetap. Individu yang tidak terpengaruh situasi lingkungan dan sosial sehingga mereka mandiri, kategori yang tepat buat mereka ialah field independent. Sebaliknya jika individu tersebut selalu menggantungkan kondisi mereka terhadap lingkungan dan keadaan sosial masyarakat kategori yang tepat buat mereka adalah kategori field dependent.Instrumen/ alat dibutuhkan guna mengukur/menentukan gaya kognitif siswa. Instrumen yang dibutuhkan ada berbagai macam salah satunya adalah Tes gambar untuk menghasilkan kelompok atau tipe yang disebut dengan tes GEFT. Siswa yang bergaya kognitif field dependent dapat dipahami pengaruh lingkungan sangat besar dan utama bagi mereka. Pola berpikir mereka global (mereka berpikir dengan menyeluruh), pemikiran analitik dan teratur/sistematik tidak terlalu dibutuhkan untuk siswa yang berpikiran seperti ini. Ilmu sosial, sangat diminati untuk siswa yang memiliki 
tipe gaya berpikir seperti ini. Hubungan sosial yang dilakukan karakter ini field dependent cenderung dapat menerima berbagai masukan/ kritikan baik itu dilakukan teman maupun guru. Tahap pemecahan masalah terdapat kesulitan untuk siswa bergaya kognitif field dependent, oleh karena itu mereka membutuhkan bantuan, dorongan/motivasi dari teman dekat, atau dari guru guna meningkatkan kepercayaannya.

Kajian teoritis dan temuan-temuan penelitian yang cukup banyak telah menunjukkan bahwa terdapat karakteristik individu yang memiliki gaya kognitif FI dan FD, serta individu yang mempunyai gaya kognitif FI menunjukkan perolehan belajar yang lebih tinggi dibandingkan dengan individu yang mempunyai gaya kognitif FD.Berdasarkan hal tersebut, peneliti berharap bahwa gaya kognitif akan terdapat pengaruh yang signifikan terhadap perolehan nilai keterampilan K3 siswa.

\section{Pengaruh metode pelatihan berbasis kompetensi dan gaya kognitif terhadap keterampilan $\mathrm{K} 3$ siswa.}

Hasil pengujian tesis ini membuktikan bahwa tidak ada hubungan antara metode pelatihan berbasis kompetensi dan gaya kognitif terhadap perolehan keterampilan K3 siswa. Dengan demikian metode pembelajaran tidak tergantung bagaimana gaya kognitifnya dalam perolehan belajar pelatihan dasar keselamatan laut. Metode Pelatihan berbasis kompetensi lebih sesuai dengan pendidikan kejuruan dibandingkan dengan metode konvensional dalam meningkatkan perolehan belajar Dasar keselamatan laut, baik yang memiliki gaya kognitif field dependent maupun field independent. Siswa yang mempunyai gaya kognitif FieldIndependent lebih bagus nilai perolehan belajar dasar keselamatan laut dibandingkan dengan siswa yang mempunyai gaya kognitif field dependent, baik yang menggunakan metode pembelajaran konvensional maupun pelatihan berbasis kompetensi.

Dalam menunjang program kompetensi lulusan siswa SMK yang siap dan dapat bersaing di dalam Dunia kerja maka diperlukan pembekalan sertifikasi kompetensi melalui uji kompetensi keahlian serta sertifikasi praktik berlayar dari perusahan pelayaran selain itu juga dibutuhkan sertifikat keterampilan bersertifikat internasional seperti sertifikat Basic Safety Training (BST) yang akan dibutuhkan siswa SMK Kemaritiman untuk masuk ke dunia pelayaran. Sehingga siswa benarbenar dibekali keterampilan yang sesuai dengan kompetensi dan siap memasuki dunia kerja.

Karakteristik proses gaya kognitif tidak adanya hubungannya langsung antara perolehan belajaran pemahamanan dengan aplikasi. Anderson dan Krathwohl (2001) merinci proses kognitif yang dilibatkan dalam aspek aplikasi yang meliputi executing dan implementing. eksekusi mencangkup keterampilan algorithmic, oleh Romiszowski dinyatakan sebagai reproductive skill, sedangkan implementasi mencangkup keterampilan dalam memecahkan masalah atau productive skill. Kemampuan tersebut membutuhkan pemahaman yang cukup mendalam dan membutuhkan keterampilan berpikir lebih tinggi. Jika dilihat dari konteks keterampilan metode pembelajaran pelatihan berbasis kompetensi, siswa dengan gaya kognitif field dependent cara penangkapan materi pembelajaran kurang tanggap jika tidak dijelaskan secara bertahap step by step langkahlangkah pembelajaran mata pelajaran beda sekali dengan siswa yang mempunyai gaya kognitif Field-Independent terkadang dengan membaca sebelum diterangkan guru sudah bisa mengikuti dan memahami materi pelajaran tersebut, sehingga siswa yang mempunyai gaya kognitiffield dependent tersebut lemah dalam penerapan keterampilan pengetahuannya sehingga harus terus dibimbing dan lebih cocok dalam pembelajaran yang fokus sentral ke guru jadi tepatnya menggunakan metode pembelajaran secara konvensional.

Penelitian ini mendukung Model Model Pembelajaran Competence Based Training (CBT) Berbasis Karakter Untuk Pembelajaran Praktik menurut Sunarso dan Paryanto (2013), mengatakan bahwa pada pengembangan metode pembelajaran menitik beratkan pada karakter siswa teknik dalam menggunakan pembelajaran kejuruan khususnya praktik kerja mesin, disaat pembelajaran praktik kerja mesin tersebut yang dibutuhkan adalah penilaian sikap siswa dan guru harus bisa menggunakan waktu praktiknya dengan tepat, dalam metode pelatihan berbasis kompetensi atau competency base training ini siswa lebih aktif dan suasana kelas ruang pembelajaran praktik mesin lebih kondusif disitulah peran nilai sikap siswa diambil selain itu nilai keterampilan saat proses kerja praktik mesin, siswa akan lebih mengerti langsung tahap-tahap 
kerja mesin dibandingkan dengan pembelajaran secara konvensional. Dengan begitu siswa akan paham dan mengetahui proses kerja mesin untuk menjadi bekal mereka lulus dan siap terjun di dunia kerja.

Dalam penelitian Amalia \& Suwatno (2016) menyatakan bahwa kompetensi siswa dapat dihasilkan berupa pemahaman pendidikan, wawasan keterampilan dan perilaku sikap untuk memasuki dunia kerja, administrasi kepegawaian, sarpras, keuangan merupakan kompetensi siswa. pengukuran dayaguna metode competency base training (CBT) daya kemahiran sangat tinggi sehingga dalam penelitiannya CBT terdapat pengaruh positif secara substansial tehadap peningkatan kompetensi siswa. Serta didapatkan dukungan penelitian hubungan gaya kognitif dengan kemampuan pemecahan matematika. Menurut Ulya (2015) bahwa kemampuan siswa dalam memecahkan masalah itu dipengaruhi oleh gaya kognitif, jika semakin tinggi nilai kognitif maka semakin pintar memecahkan masalah matematika.

Dukungan secara teoritis dan empiris terhadap adanya pengaruh utama metode pendidikan dalam kegiatan pembelajaran dan pengaruh utama Gaya Kognitif terhadap keterampilan K3 siswa berdampak terhadap lemahnya hubungan metode pembelajaran dan gaya kognitif terhadap keterampilan $\mathrm{k} 3$ siswa. sesuai dengan penelitian tesis ini yang menyatakan tidak ada hubungan antara metode dengan gaya kognitif terhadap keterampilan $\mathrm{k} 3$ siswa.

\section{SIMPULAN}

Berdasarkan pengujian hipotesis dan pembahasan, dapat disampaikan beberapa kesimpulan hasil penelitian antara lain yaitu; (1) adanya pengaruh perolehan hasil Keterampilan K3 siswa dengan menggunakan metode konvensional dan metode Pelatihan berbasis kompetensi. (2) adanya pengaruh Keterampilan K3 siswa antara gaya kognitif baik gaya Kognitif Field-Independent maupun field dependent. (3) tidak ada hubungan antara metode dan gaya kognitif terhadap keterampilan K3 siswa.

Secara umum metode pembelajaran konvensional dan pelatihan berbasis Kompetensi dengan gaya kognitif tidak menunjukkan adanya pengaruh hubungan terhadap keterampilan K3 siswa. Metode Pelatihan berbasis kompetensi lebih efektif dibandingkan metode konvensional dalam meningkatkan keterampilan K3 siswa, baik siswa yang memiliki gaya kognitif field dependent maupun siswa yang memiliki gaya kognitif field independent. Untuk Siswa yang memiliki gaya kognitif field independent nilai keterampilan k3nya lebih kompeten dibandingan dengan siswa yang mempunyai gaya kognitif Field-Dependent, baik yang menggunakan metode konvensional maupun pelatihan berbasis Kompetensi (PBK). Selanjutnya implementasi penerapan metode pelatihan berbasis kompetensi disarankan sebagai metode pembelajaran Sekolah Menengah Kejuruan mata pelajaran produktif demi pencapaian pengetahuan kompetensi keahlian serta keterampilan siswa yang ada di SMK.

\section{REFERENSI}

Aldarmono, A. (2012). Identifikasi gaya kognitif (cognitive style) peserta didik dalam belajar. Al-Mabsut: Jurnal Studi Islam Dan Sosial, 3(1), 63-69.

Amalia, L., \& Suwatno, S. (2016). Peningkatan kompetensi siswa melalui efektivitas competency based training. Jurnal Pendidikan Manajemen Perkantoran (JPManper), 1(1), 30-37.

Fauzi, M.(2019). PengaruhStrategi Pembelajaran Swa-Atur Dengan Discovery Learning dan Gaya Kognitif Terhadap Hasil Belajar Kimia. Edcomtech Jurnal Kajian Teknologi Pendidikan, 4(1), 56-66.

Hidayat, A. I., \& Sa'ud, U. S. (2015). Model Pendidikan dan Pelatihan Berbasis Kompetensi bagi Widyaiswara Muda. Jurnal Administrasi Pendidikan, 22(2), 23-38.

Kemdikbud. (2017). Modul Pelatihan Implementasi Kurikulum 2013 SMK. Jakarta: Direktorat PSMK, Kementerian Pendidikan dan Kebudayaan.

Kuswandi, D., Surahman, E., Thaariq, Z. Z. A., \& Muthmainnah, M. (2018). K-Means Clustering of Student Perceptions on Project-Based Learning Model Application. 2018 4th International Conference on Education and Technology (ICET), 9-12. Malang, Indonesia: IEEE. doi: 
10.1109/ICEAT.2018.8693932

Murtafiah, M. (2017). Deskrkipsi Kemampuan Pemecahan Masalah Matematika Ditinjau Dari Gaya Kognitif Mahasiswa Pendidikan Matematika Universitas Sulawesi Barat. Jurnal Pendidikan MIPA, 7(1), 48-52.

Mustafid, M. F., Wedi, A., \& Adi, E. P. (2020). Perbedaan Indeks Prestasi Kumulatif (IPK) Berdasarkan Gaya Belajar pada Mahasiswa Jurusan Teknologi Pendidikan Universitas Negeri Malang Angkatan 2017. JINOTEP (Jurnal Inovasi Dan Teknologi Pembelajaran): Kajian Dan Riset Dalam Teknologi Pembelajaran, 6(2), 119-128.

Ningrum, T. W. A., Degeng, I. N. S., \& Ulfa, S. (2019). Implementasi Kurikulum Muatan Lokal Keterampilan Batik Di Sekolah Menengah Pertama Negeri 2 Bantur Kabupaten Malang. Jurnal Kajian Teknologi Pendidikan, 2(3), 245-251.

Ningsih, R., \& Sudira, P. (2016). Penerapan Model Pembelajaran Kooperatif Make A Match Untuk Meningkatkan Keaktifan dan Hasil Belajar Siswa dalam Mata Pelajaran Memahami Sifat Dasar Sinyal Audio Kelas X Audio Video di SMK Negeri 1 Saptosari. E-JPTE (Jurnal Elektronik Pendidikan Teknik Elektronika), 5(3), 3741.

Nurhajati, W. A., \& Bachri, B. S. (2018). Pengembangan Kurikulum Diklat (Pendidikan dan Pelatihan) Berbasis Kompetensi dalam Membangun Profesionalisme dan Kompetensi Pegawai Negeri Sipil (PNS). JP (Jurnal Pendidikan): Teori Dan Praktik, 2(2), 156-164.

Paryanto, P., Soemawidagdo, A. L., \& Sunarso, S. (2013). Model Model Pembelajaran Competence Based Training (Cbt) Berbasis Karakter Untuk Pembelajaran Praktik. Jurnal Kependidikan: Penelitian Inovasi Pembelajaran, 43(2), 124-133.

Prayogo, D., Arifin, M. Z., Erliyani, D., \& Yuntoro, K. (2018). Evaluasi Diklat Program Pelatihan Keselamatan Dasar bagi calon Pelaut. Penguatan Pendidikan Karakter Pada Siswa Dalam Menghadapi Tantangan Global, 29-33.

Purwanti, R. D., Pratiwi, D. D., \& Rinaldi, A. (2016). Pengaruh Pembelajaran Berbatuan
Geogebra terhadap Pemahaman Konsep Matematis ditinjau dari Gaya Kognitif. Al-Jabar: Jurnal Pendidikan Matematika, 7(1), 115-122.

Reni, Y. M., \& Kuswandi, D. (2018). Pengaruh Strategi Pembelajaran Dan Self Regulated Learning Terhadap Hasil Belajar. JINOTEP (Jurnal Inovasi Dan Teknologi Pembelajaran): Kajian Dan Riset Dalam Teknologi Pembelajaran, 4(1), 47-55.

Riding, R., \& Rayner, S. (2013). Cognitive styles and learning strategies: Understanding style differences in learning and behavior. Routledge.

Sanjaya, N. M. S. (2018). Pengaruh Metode Problem Solving dan Gaya Kognitif terhadap Kemampuan Analisis Siswa. Indonesian Journal of Economic Education (IJEE), 1(1), 65-71.

Santosa, P. S. (2018). Pengelolaan Kecelakaan Pada Kapal. Majalah IImiah Bahari Jogja, 16(1), 54-64.

Setyowati, L., Suroto, S., \& Kurniawan, B. (2016). Analisis Implementasi Rencana Tanggap Darurat (Emergency Response Plan) Pada Kapal Penumpang X. Jurnal Kesehatan Masyarakat (e-Journal), 4(3), 478-486.

Surachim, A. (2013). Dual education system (PSG) effectiveness to improving SMK graduates quality. International Journal of Science and Research (IJSR), 2(6), 421425.

Susanto, H. A. (2015). Pemahaman Pemecahan Masalah Berdasar Gaya Kognitif. Deepublish.

Ulya, H. (2015). Hubungan Gaya Kognitif Dengan Kemampuan Pemecahan Masalah Matematika Siswa. Jurnal Konseling Gusjigang, 1(2), 107353.

Wedi, A. (2017). Konsep dan masalah penerapan metode pembelajaran: Upaya peningkatan mutu pembelajaran melalui konsistensi teoritis-praktis penggunaan metode pembelajaran. Edcomtech Jurnal Kajian Teknologi Pendidikan, 1(1), 21-28.

Yamin, M. (2020). Perilaku keselamatan dan kesehatan kerja siswa dalam pembelajaran praktikum di SMKN 2 Sidenreng. Jurnal of Admiration, 1(3), 207-214. 